\title{
The specificities of the circular economy (CE) in the municipal wastewater and sewage sludge sector-local circumstances in Poland
}

\author{
Malgorzata J. Kacprzak ${ }^{1}$ (D) - Iwona Kupich ${ }^{1}$ (D)
}

Received: 30 January 2021 / Accepted: 19 July 2021 / Published online: 4 August 2021

(c) The Author(s) 2021

\begin{abstract}
Wastewater treatment plants (WWTPs) have become crucial elements of the regional bioeconomy-mainly through energy (waste to energy) and matter (nutrients-energy-water) recovery as an element of sustainable development of a smart city. In Poland, a decentralized system functioned with 3278 municipal wastewater treatment plants, and less than $80 \%$ of the population were connected to public urban wastewater treatment systems. The paper presents the technology selection and implementation of circular economy at WWTPs and the practical approach to challenge of energy-positive and environmentally friendly wastewater and sewage sludge sector. The modernization of technological lines of wastewater treatment has led to a significant improvement in the quality of treated sewage, at the largest WWTPs in Warsaw, Cracow, or Gdansk. Eleven WWTPs produce $34 \%$ of the total volume of approximately $337 \mathrm{GWh}$ of electricity from biogas in Poland. The potential of producing electricity from biogas in WWTPs in Poland can be estimated at approximately $700-850 \mathrm{GWh}$ per year. According to the data of the Statistics Poland in Poland, approximately 25\% of sewage sludge was used directly in agriculture and for land reclamation. Simultaneously, more than 100 WWTPs produce compost at a high quality. However, only few produce organic/organic-mineral fertilizers, mainly with addition of calcium. Decentralization leads to different technologies used in wastewater treatment plants, and environmental, economic, and social conditions determine the direction of changes and introduction of a circular economy paradigm in the Polish wastewater sector.
\end{abstract}

Malgorzata J. Kacprzak

malgorzata.kacprzak@pcz.pl

1 Department of Environmental Engineering and Biotechnology, Faculty of Infrastructure and Environment, Czestochowa University of Technology, Częstochowa, Poland 


\section{Graphic abstract}

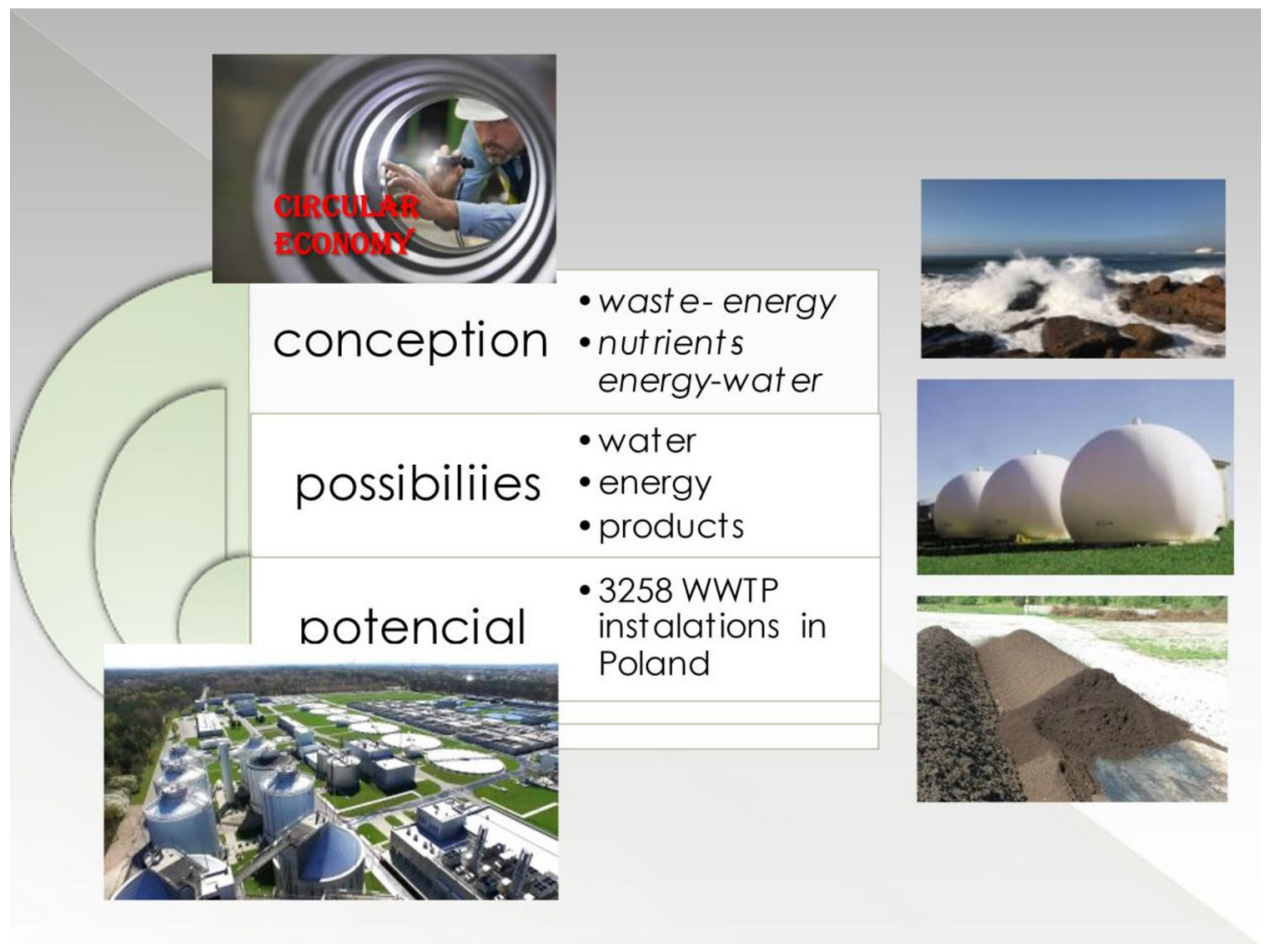

Keywords Wastewater treatment · Circular economy · Sewage sludge management · Biogas · Energy self-sufficiency · Poland

\section{Introduction}

"Closing the loop-an EU action plan for the circular economy" from 2015 (EC 2015) indicated a departure from the traditional linear economy model based on obtaining raw materials, production, and use and waste disposal. In the new approach, the value of products, materials, and resources is retained for as long as possible. However, it is common knowledge that these assumptions can be introduced only sequentially, forcing industrial symbiosis and the following innovation, resulting from the need to create new technological solutions, measurement methods or devices. One of the service facilities in which the "circular economy" (CE) model assumptions can be successfully implemented is the water and sewage industry. CE model framework in the water and wastewater sector includes the six following actions: (i) reduction-prevention of wastewater generation by the reduction of water usage and pollution reduction at the source; (ii) reclamation (removal) an application of effective technologies for the removal of pollutants from water and wastewater; (iii) reuse-reuse of wastewater as an alternative source of water supply (nonpotable usage); (iv) recycling-recovery of water from wastewater for potable usage; (v) recovery-recovery of resources such as nutrients and energy from water-based waste; and (vi) rethink-rethinking how to use resources to create a sustainable economy, which is 'free' of waste and emissions (Smol et al. 2020). Despite many existing technologies and strategic documents at the EU (2016, 2020) or national level, it is difficult to apply these solutions comprehensively in practice, combining wastewater treatment with the production of energy, fertilizers, saving water and reducing the negative impact on the environment at the regional level. Both the European Green Deal and the Circular Economy Action Plan (CEAP) accept the importance of recycling of materials as a priority area, which are in line with circular economy principles. The new Regulation (EU) 2020/741 on minimum requirements for water reuse for agricultural irrigation of May 25, 2020, will apply from June 26, 2023, and is expected to stimulate and facilitate water reuse in the EU; however, the new regulation comes with strict circumstances for water quality requirements. Moreover, scientific progress and technological developments as well as changes in the policy landscape (resulting from the first and second CEAP, the Bioeconomy Strategy, the new Fertilising Products 
Regulation, the Farm to Fork Strategy, the EU Biodiversity Strategy for 2030, and the recently evaluated Urban Wastewater Treatment Directive 91/271/EEC (UWWTD)), resulted in the Commission's decision to revise the Sewage Sludge Directive (86/278/EEC).

The transformation of WWTPs and/or biowaste facilities from "the strategy one goal" (wastewater and waste treatment) into "the CE strategy" as biorefineries (Tobin et al. 2020), biopower (Pott et al. 2018) or even biomaterial producers (You et al. 2019) is becoming more realistic nowadays. Currently, WWTPs should be an area where these assumptions can be successively implemented through (Neczaj and Grosser 2018; Qui et al. 2019; Sfez et al. 2019; Maroušek et al. 2020): (i) closed water and wastewater cycles, (ii) recovery of valuable substances (nitrogen, phosphorous, cellulose, humic acids, fatty acids, enzymes, and polysaccharides), (iii) recovery of products generated in technological processes (fertilizers and biochar), and (iv) recovery of energy and heat. However, European WWTPs frequently operate within the linear economy paradigm with the main target connected with wastewater treatment at the suitable level. Part of them understands the necessity to improve energy efficiency and increase matter recovery; however, there is lack of both a practical approach and welldocumented cases in this subject.

Kehrein et al. (2020) calculating market supply potentials of water, energy, fertilizer, and other products recoverable from municipal WWTPs in the Netherlands or Flanders identified the potential resource recovery and market supply potential. They found on the basis of data from 11 WWTPs that advanced technologies used for water recovery, such as microfiltration and ultrafiltration, could reduce Dutch freshwater use by $17 \%$, while reverse osmosis could reduce it by $13 \%$. In spite of the fact that WWTPs can reuse the treated effluent in the system, contributing to the closure of the water cycle and avoiding the pumping of treated water into the sea (like Spain does, for instance), the important questions regarding the illegal connection of waste pipes with traditional irrigation or the payment of pumping costs for reuse have gone unanswered, and there is a need for better reflection from all stakeholders (Hagenvoort et al. 2019). Trimmer et al. (2017) recognized that in developed countries, replacing existing sanitation systems will account for most of the total resource recovery potential (77-84\%) and could offset between 4 and $12 \%$ of projected synthetic fertilizer use. It is extremely important, because $55 \%$ of phosphorous in European countries is lost through wastewater systems (van Dijk et al. 2015). In spite of the exciting number of technologies of phosphorous recovery, only Switzerland and Germany introduced legislation requiring $P$ recover and recycling for the wastewater treatment sector.

The subject of the presented work is to determine the implementation of circular economy principles in the wastewater sector in Poland. The specific goal of this work was the estimation of installations at WWTPs that in practice displayed the effectiveness of combining different ways of proceeding during wastewater treatment in the context of water-nutrient-energy-recovery under the national/EU legislation.

\section{Statistical data in polish wastewater sector}

Statistical data were collected from Statistics Poland (2020). It is estimated that almost $61 \%$ of people in Poland live in cities (the average for Europe is 74.4\%). In 2019, there were 3278 municipal wastewater treatment plants (which support $75 \%$ of the Polish population), 2055-with a throughput up to $500 \mathrm{~m}^{3}$ of sewage per day-and another 878 with a throughput between 501 and $5000 \mathrm{~m}^{3}$ per day. This is a total of over $90 \%$ of all municipal sewage treatment plants, but their share in the "production" of treated wastewater is only $19 \%$. In addition, the number of treatment plants in the years between 2000 and 2019 serving cities increased from 801 to 938 , while in the villages, simultaneously, the number of treatment plants increased from 1510 to 1965 . The largest percentage of the population using sewage treatment plants was recorded in the province Zachodniopomorskie (83\%), and the lowest was in the province of Lublin-58\%. At the same time, almost $95 \%$ of the population use sewage treatment plants, while in villages it is $44 \%$. It has been estimated that $96.6 \%$ of the urban population have access to the treatment plant in the provinces of Kuyavian-Pomeranian, Podkarpackie, and Podlaskie regions; the least- $-91 \%$ in Silesia. As for the village population, the highest percentage is at $62.1 \%$ in the Pomeranian province, and the least is at 22.8\% in the Podlaskie region. For comparison, in 2017, most European countries collected and treated sewage to a tertiary level from most of their population. In EU-27 countries, $69 \%$ of the population were connected to tertiary level treatment and $13 \%$ to secondary level treatment. Countries where less than $80 \%$ of the population were connected to public urban wastewater treatment systems include: Albania, Bosnia and Herzegovina, Bulgaria, Croatia, Ireland, Italy, Lithuania, Romania, Serbia, Slovakia, and Slovenia (EEA 2020a).

The amount of sewage sludge is about $1-3 \%$ of the volume of sewage operated at WWTP; however, it can pose a potential threat to the environment if managed inappropriately. In Poland, sewage sludge is used for: agricultural purposes, fertilization of soils and plants as a valuable source of nitrogen and phosphorus, compost production, as well as for the reclamation of degraded lands (Fig. 1). It has been noted that between years of 2000 and 2019, there was a significant decrease in the volume of sewage sludge distinguished in landfill (from 43 to $1.6 \%$ ) and an increase in the volume of 
Fig. 1 The sewage sludge management between years of 2000 and 2019, performed their own study based on Statistics Poland data, (https://stat.gov.pl/en)

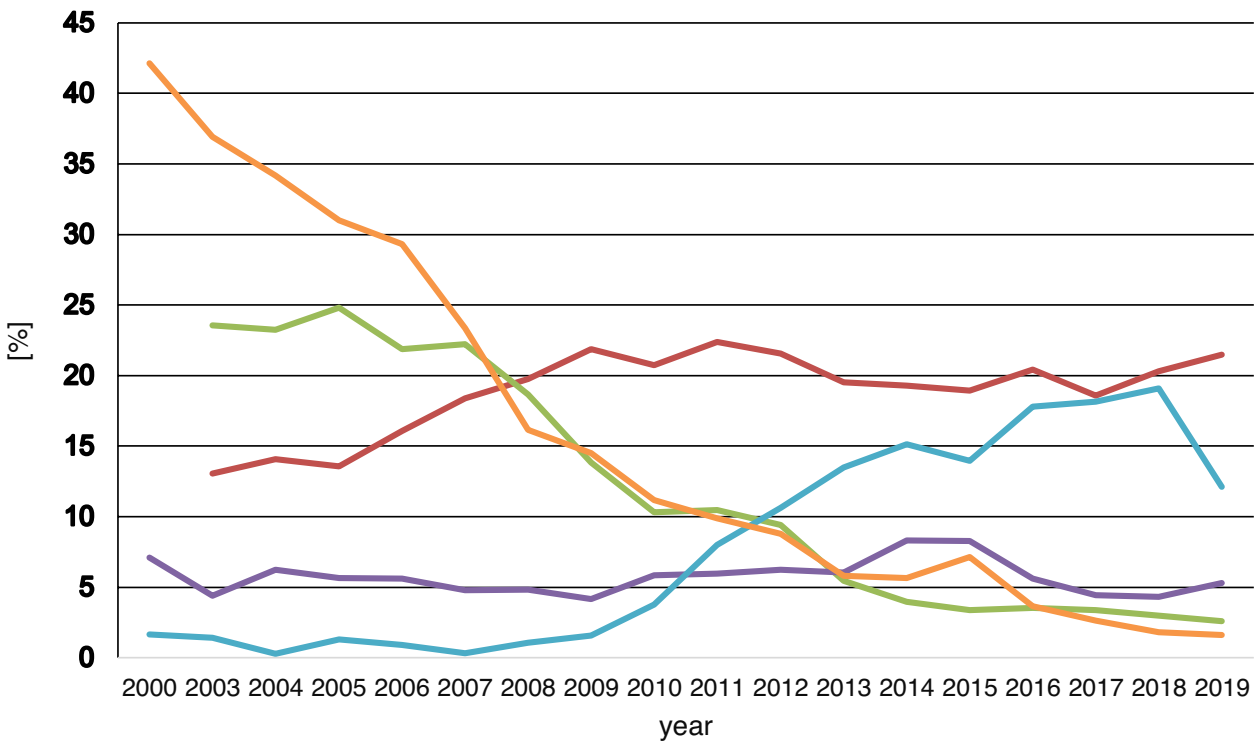

$\longrightarrow$ agriculture $\longrightarrow$ reclamation $\longrightarrow$ plant cultivation for compost $\longrightarrow$ incineration $\longrightarrow$ landfilling incinerated-from $1.4 \%$ to $19.1 \%$ (2018) and 12.1 (2019). Bianchini et al. (2016) analyzed statistical data (Eurostat, EC reports) concerning sewage sludge production and disposal and found two important considerations: (i) unknown disposal in EU-27 was too high to make a consistent analysis and was equal $10.7 \%$, (ii) agriculture was the preferred disposal route in EU-27. In Poland, the difference between the sewage sludge produced and the one disposed was even higher and equal to $57 \%$ in 2019. According to Bianchini et al. (2016), such highly unknown disposal routes of sewage sludge disposal is very dangerous due to the possibility of fully disappeared from the official amount, since it is even practically realized as a sludge landfilling or land spreading.

\section{The wastewater treatment plant (WWTP) as an element of the "circular economy" concept}

\section{Protection of natural resources-biowater, bioresources, and biorecycling-theoretical base and national legislative solutions}

The water and sewage sector offers many possibilities for implementing activities based on the closed cycle model-in both unitary and broader terms, assuming inter-branch cooperation. This, however, involves a change in the perception of waste generated during wastewater treatment processes and the creation of clear definitions and legislation allowing for multidirectional development in this area of the management. Until recently, WWTPs were associated with only one goal-bringing contaminated sewage to such a quality that they could be safely discharged into the environment. At present, the wastewater treatment plant represents not only a conventional bioprocessing facility, but is more often utilized as a bioenergy plant (biogas production) or even a biorefinery (Gherghel et al. 2019). In theory, many strategies/technologies are being proposed for improving energy self-sufficiency at wastewater treatment plants (WWTPs); however, limited case studies have been reported. As mentioned by Vij et al. (2021), the centralized and decentralized systems of wastewater treatment may use different technologies. They compared three aspects, representing the wastewater paradigms in India and the Netherlands: (1) framing, (2) policy goals, and (3) technical and financial instruments. They found that in both countries the paradigms have evolved. In India, the main concept is actually focused on "water scarcity and beautification of cities." In the case of the Netherlands, the wastewater paradigms have changed from an emphasis on "public health and environmental concerns" to the "circular economy of wastewater" and governance strategies to increase the urban wastewater treatment capacity and reuse are developed. Contrary to the Netherlands, significant progress toward wastewater treatment and reuse has been made. Wallis-Lage et al. (2015) suggest that the best option is an equal priority between the waste to energy (WtE) approach that uses the potential of sewage sludge (but also other organic waste) to generate energy, as well as the new nutrient-energy water paradigm (NEW), (Fig. 2). Both define the future role of WWTPs and its share in creating the national concept of the/a circular economy in relation to municipal infrastructure (Karło and Gieleciak 2018). On the other hand, Villarín and Merel (2020)marked the following paradigms: (i) water reuse 
Fig. 2 Resource recovery ways within the nutrient-energy water paradigm (NEW), (Wallis-Lage et al. 2015)

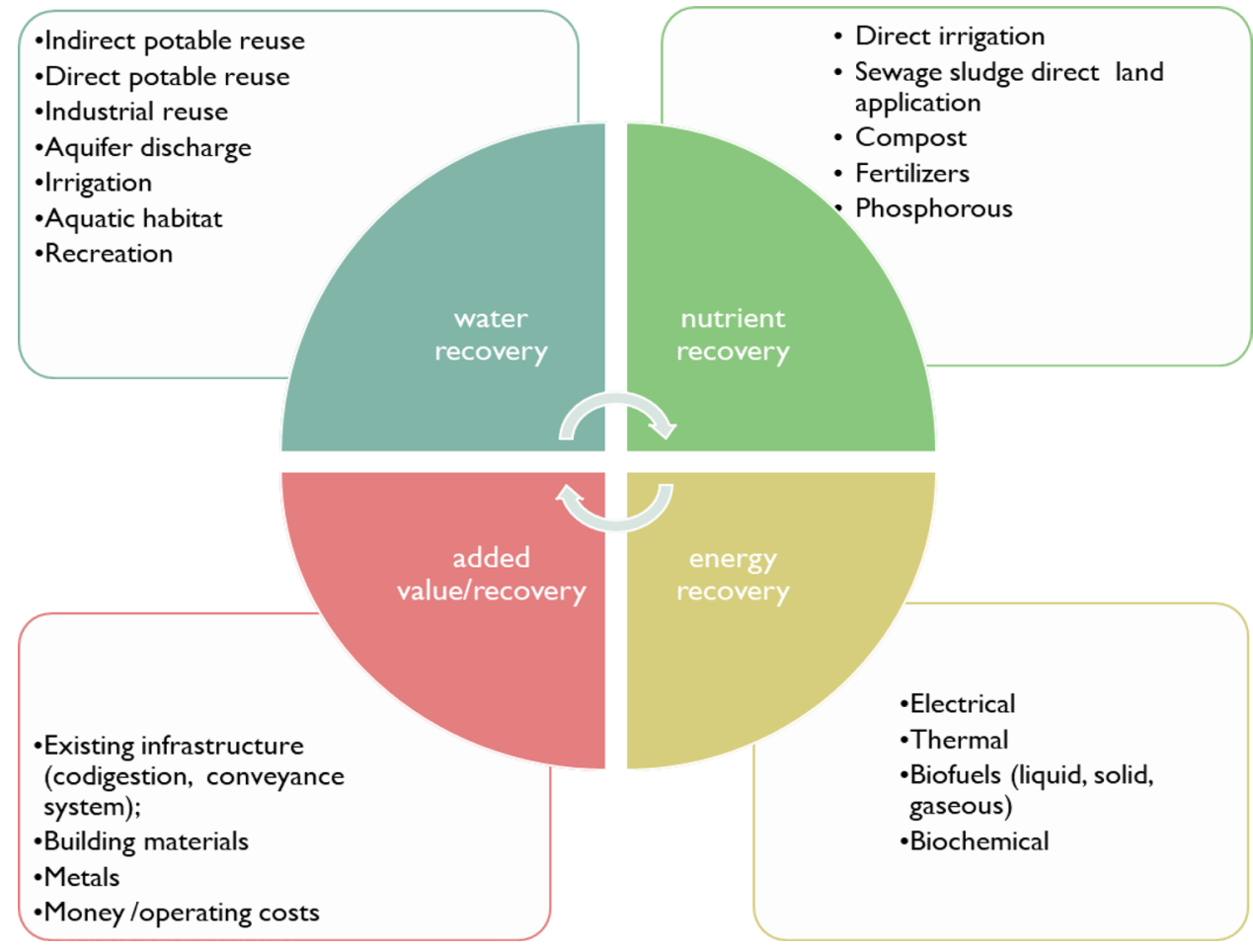

considering wastewater as a water resource rather than a hazardous waste, (ii) wastewater-based epidemiology considering wastewater as a source of information regarding the overall health of a population through the analysis of specific biomarkers, (iii) circular economy through the implementation of treatment processes aiming at harvesting valuable components such as precious metals or producing valuable goods such as biofuel. The authors mentioned that approaching "water reuse" should also take public acceptance into consideration. The necessity of design and the introduction of such an approach were described by Montwedi et al. (2021) in the research concerning rural South Africa. They noted that at the same time WWTPs consume large amounts of energy to comply with discharge standards, and wastewater contains resources that can be recovered for secondary uses, if treated properly. According to the authors, the conversion of wastewater treatment systems into low cost and environmentally sustainable water and resource recovery facilities should be widely introduced.

Actually, the most attention is paid to the following aspects: (i) management of treated wastewater (water renewal and reuse) and (ii) reduction in the loss of nutrients and decrease contamination of aquatic environments (removal and recovery of nutrients). Moreover, considering market potentials, technological innovations, early in the planning and process design phase, may facilitate the design, including: (i) improving the quality and conditions of the water and soil environment by removing harmful micropollutants as well as removing and recovering nutrients, (ii) reducing the consumption of water resources by water reuse, (iii) improving the living conditions of the society in connection with the developed water and sewage management system, (iv) reduction in the extraction of minerals used in the production of mineral fertilizers used in agriculture, (v) reducing the nuisance of the sewage treatment plant to its immediate surroundings (reduction of odor emissions), and (vi) low construction and operation costs of new and modernized wastewater treatment plants through, inter alia, increasing energy self-sufficiency.

EU legislation should be followed by regulation at the national level. The Polish "Strategy for dealing with municipal sewage sludge for 2019-2022" (Ministry of Environment, 2018) in order to ensure a proper method of dealing with municipal sewage sludge assumes the following strategic objectives:

(1) The decrease in the total amount of sewage sludge, especially of poor quality produced in municipal wastewater treatment plants. In accordance with regulations, the suitable use of sewage sludge, directly on the surface of the land, for production of fertilizers, plant suppliers or thermal treatment for energy recovery.

(2) Increasing the amount of municipal sewage sludge treated before entering the environment and increasing the amount of municipal sewage sludge thermally treated.

(3) Striving to maximize the degree of use of biogenic substances contained in sewage sludge while meeting all requirements regarding sanitary, chemical and environmental safety. 
These regulations are not enough to achieve the circular model of WWTP in the area of waste management; however, it can be the starting point for further entries.

\section{Area of technology}

There are several new technologies, especially used in the operation of wastewater treatment plants, which have been implemented over the last few years in accordance with the "smart" idea and CE. The following directions of development of technology have been developed for the operation of WWTP's in Poland (Rybicki 2019): (i) increasing the technological and functional efficiency of the WWTPs based on multi-phase biological reactors for the integrated removal of carbon, nitrogen and phosphorus compounds, and in justified cases, the development of technology to the water reuse in accordance with appropriate quality standards; (ii) implementation of technical solutions ensuring low energy consumption, not only by using devices with low electricity consumption (e.g., blowers, pumps, and mixers) but, above all, activities focused on the recovery of some energy in the technological process so as to use it as a renewable energy. First of all, it is the combined production of electricity and heat with the use of fermentation gas generated during the anaerobic treatment of sewage sludge. It can also be the use of heat pumps using sewage as the so-called lower source. Finally, there are some examples of the use of large, woodless land occupied by wastewater treatment plants as an area for solar farms; (iii) an example of the application of a technology that significantly reduces electricity consumption is the introduction of nitrogen removal by nitrification instead of the much more energy-consuming denitrification; (iv) minimization of the volume of sludge after the end of the technological process and the possibility of their disposal/ use - to minimize the negative impact on the environment ("ecological footprint") and the use of such methods of sludge treatment, which are characterized by lower electricity consumption than traditional methods.

\section{Water supply potential}

The data of the European Commission show that every year in the EU more than 40 billion $\mathrm{m}^{3}$ of sewage is treated, and less than 1 billion $\mathrm{m}^{3}$ is reused. On June 25, 2020, the Regulation of the European Parliament on the minimum requirements for water reuse came into effect, which included provisions on the use of municipal wastewater for irrigation of agricultural land. The new rules will apply from June 26, 2023, and are designed to stimulate and facilitate water reuse in the EU. In spite of the fact that water reuse is mainly a local solution to a local problem, water stress and balance of costs and benefits should be analyzed on a national, regional or river basin scale.
However, it should be taken into consideration that the sewage (even after treatment) contains many contaminants (emerging contaminants) that are not standardized and may pose a threat to the environment. Hence, it is necessary to use tertiary treatment, which is a final process that improves wastewater quality before it is reused, recycled or discharged. Unfortunately, the process is usually very expensive. An important issue is also the social acceptance of wastewater reuse directly from WWTP (Kehrein et al. 2020). According to Wallis-Lage et al. (2015), the water can be reused in: (i) agriculture/horticulture such as irrigation of crops (food and non-food), orchards and pastures or aquaculture including algal farming; (ii) industry such as cooling water, process water, aggregate washing, concrete making, soil compaction, dust control and/or iii) municipal/landscape uses such as irrigation of public parks, recreational and sporting facilities, private gardens, roadsides, street cleaning, fire protection systems, vehicle washing, toilet flushing. In the document, several environmental, economic and social benefits are shown. Kehrein et al. (2020) estimated that wastewater discharged by Dutch WWTPs account for only $20 \%$ of the total amount of fresh water abstracted in the Netherlands. Generally, authors calculate that application of filtration technology, such as microfiltration and utrafiltration to wastewater, entails a loss of water by $17 \%$ and reverse osmosis by $13 \%$. They are more skeptical in relation to the use of advanced treatment of wastewater to obtain good quality water to drink. In their opinion, only latter technology could reclaim water of a high enough quality to enter the potable supply. In Poland, a good example is the use of approximately 1.5 million $\mathrm{m}^{3}$ of sewage treated from the "Dabrowka Mala" WWTP operated by Katowickie Wodociagi S.A. by the neighboring heat and power plant belonging to Tauron Heat Sp. z o.o.-Katowice Production Plant. It has been calculated that during the 20 years of operation of the installation, it allowed for the savings of about 30 million $\mathrm{m}^{3}$ of drinking water (Konopka 2019). On the other hand, at the Chrzanow Trzebinia Group WWTP since 2019, treated sewage (as a "technological water") has been used for the operation of the grate building: to a screenings washer and directly to a sand separator with a sand washer. In addition, treated wastewater will be used at WWTP not only to rinse the tanks, but also to wash specialized vehicles used for wastewater transport (Wyrwik 2020). At the WWTP Tychy, treated wastewater is used as technological water. Recirculant (meeting the necessary parameters) is used by power generators, a sewage sludge dewatering station, a biogas purification station, and is also used for car washing. This approach resulted in the reduction of tap (drinking) water consumption from 185.5 to 117 thousand $\mathrm{m}^{3}$ per year (Karło and Gieleciak 2019). In EU countries, over 40 billion $\mathrm{m} 3$ of sewage is 
treated every year, however only 964 million $\mathrm{m} 3$ of treated wastewater is reused, which is only $2.41 \%$ of the potential stream (Strategy 2016).

\section{Wastewater treatment efficiency}

High requirements to the degree of wastewater treatment, particularly with regard to the elimination of nitrogen and phosphorus, have far-reaching consequences for the construction and operation of treatment plants and lead to rapidly growing technological progress, especially in terms of process techniques. This applies to both large and small sewage treatment plants. Within project IWAMA there was an estimated efficiency of wastewater treatment of 66 WWTPs in the Baltic Sea Region (Finland, Sweden, Denmark, Germany, Poland, Lithuania, Latvia, Estonia, Belarus, Russia). According to Rettig et al. (2018), in all these regions, the activated sludge system with nitrification and denitrification can be considered as the dominant or even exclusively applied technology. The sequential biological reactor (SBR) was most frequently used in the Baltic Sea region for wastewater treatment; however, they were conventional multistage flow systems. Only two WWTPs in the South-Baltic region use other technology - a fan-activated sludge system in combination with a biological trickle bed, a USB reactor, and a two-stage biofiltration and CASS (Cyclic Activated Sludge System) sequence reactor. The largest wastewater treatment plant in Poland, which is called "Czajka" in Warsaw, was established in 1991, and after the modernization and adaptation of the technology to the applicable regulations in the field of wastewater treatment, it increased its capacity from $240,000 \mathrm{~m}^{3} /$ day to $435,300 \mathrm{~m}^{3} /$ day. The sewage treatment plant uses a conventional system to wastewater treatment. The first stage of wastewater treatment is mechanical treatment. Wastewater is transferred to the grates and is then sent to sand traps and preliminary settling tanks. In the second stage, they are directed to the activated sludge reactors with an enhanced biogen (N, P) removal system (Fig. 3). The sewage from the reactors goes to a final clarifier, where the activated sludge is separated from the sewage, which is then discharged to the Vistula River.

WWTP has 10 BIODENIPHO technological lines. Each technological line is equipped with one biological reactor with Bio-P systems for phosphorus removal, Biodenitro for nitrogen removal, two aeration chambers, two final clarifiers and an activated sludge recirculation system. The efficiency of the "Czajka" wastewater treatment system is presented in Table 1 in comparison with data from other WWTPs located in the largest Polish cities.

To achieve specific effluent goals for BOD, nitrogen and phosphorus, different adaptations and modifications have been made to the basic activated sludge design. Well known modifications include sequencing batch reactors (SBR), oxidation ditches, deep shafts, extended aeration, moving beds and membrane bioreactors. In WWTP Tychy, as part of numerous investments at the WWTP, two independent technological lines for biological wastewater treatment with the removal of biogenic compounds were introduced. First of all, wastewater treatment is realized according to the patented, modern and one of the largest in Poland, C-Tech technology, based on SBR sequential reactors. The second, in the process of purification, uses activated sludge chambers that work according to the technology of integrated, highly effective removal of nitrogen and phosphorus. The modified Johannesburg (JHB) system consists in the distribution of the inflow to the pre-denitrification chamber (20\%) and the anaerobic chamber (80\%). Recently, Song et al. (2020) developed a Johannesburg-Sulfur autotrophic denitrification system (JHB-SAD) to treat municipal wastewater. According to authors, the JHB-SAD could achieve the complete removal of nitrogen, and theoretically the nitrogen removal efficiency is independent of the COD/TN ratio. Moreover, the system achieved the phosphorus removal above $90 \%$ with a dosing of a small amount of sodium acetate (chemical oxygen demand, COD of $40 \mathrm{mg} / \mathrm{L}$ ). At the WWTP Tychy after modernization, a better quality of wastewater was obtained (Fig. 4). The use of the technology C-TECH was more effective in the case of the reduction of COD/BOD-42/86\%
Fig. 3 The block diagram of the biological system of the WWTP Czajka, Warsaw (MPWiK, Warsaw)

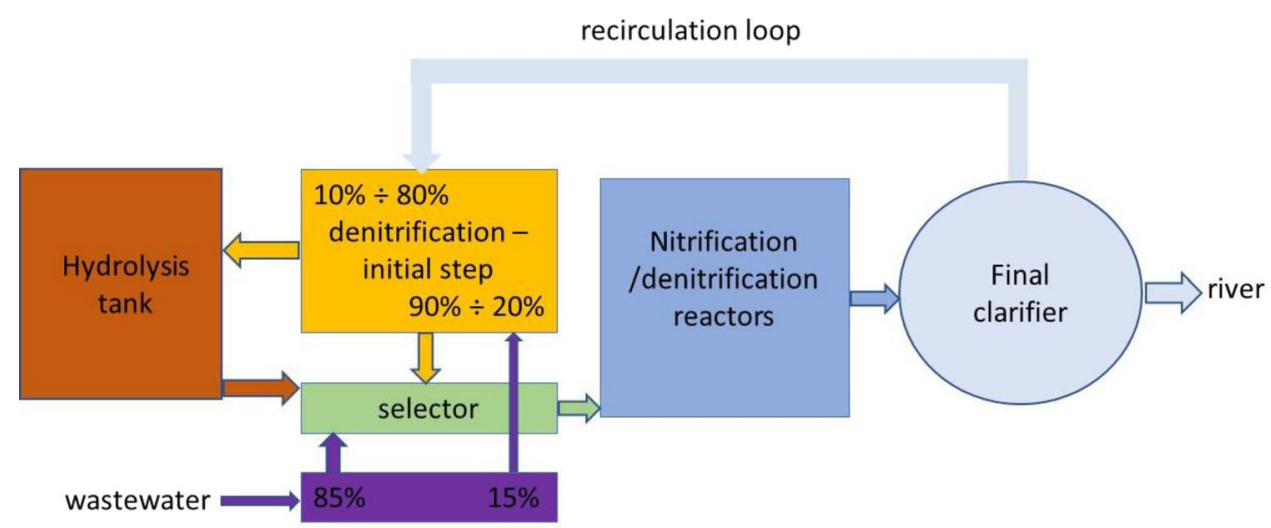


Table 1 The comparison of wastewater treatment efficiency from different Polish cities - the quality of treated wastewater

\begin{tabular}{|c|c|c|c|c|c|c|c|c|c|}
\hline \multirow[t]{2}{*}{$\begin{array}{l}\text { WW quality } \\
\text { indicator }^{\mathrm{a}}\end{array}$} & \multicolumn{2}{|c|}{$\begin{array}{l}\text { WWTP "Czajka" } \\
\text { Warsaw }^{\text {b }}\end{array}$} & \multicolumn{2}{|c|}{$\begin{array}{l}\text { WWTP "Plaszow" } \\
\text { Cracowc }\end{array}$} & \multicolumn{2}{|c|}{$\begin{array}{l}\text { WWTP "Saur Neptun" } \\
\text { Gdansk }^{\text {d }}\end{array}$} & \multirow{2}{*}{$\begin{array}{l}\text { WWTP } \\
\text { "Pomorzany" } \\
\text { Szczecin }\end{array}$} & \multirow[t]{2}{*}{ WWTP Lodz } & \multirow[t]{2}{*}{ WWTP Lublin } \\
\hline & $\begin{array}{l}\text { Before } \\
\text { moderni- } \\
\text { zation }\end{array}$ & $\begin{array}{l}\text { After } \\
\text { moderni- } \\
\text { zation }\end{array}$ & $\begin{array}{l}\text { Before } \\
\text { moderni- } \\
\text { zation }\end{array}$ & $\begin{array}{l}\text { After } \\
\text { moderni- } \\
\text { zation }\end{array}$ & $\begin{array}{l}\text { Before } \\
\text { moderni- } \\
\text { zation }\end{array}$ & $\begin{array}{l}\text { After } \\
\text { moderni- } \\
\text { zation }\end{array}$ & & & \\
\hline BOD $\mathrm{mgO}_{2} / \mathrm{dm}^{3}$ & 7.2 & 3.3 & 128 & 11.2 & 7.4 & 3.3 & 4.1 & 8.5 & 4.9 \\
\hline $\mathrm{COD} \mathrm{mgO}_{2} / \mathrm{dm}^{3}$ & 49 & 34 & 239 & 125 & 39 & 36.1 & 32 & 51.4 & 27.3 \\
\hline $\begin{array}{l}\text { Total Suspended } \\
\text { Solids } \mathrm{mg} / \mathrm{dm}^{3}\end{array}$ & 13.4 & 6.1 & 105 & 35 & 19.3 & 5.3 & 6.3 & 15.4 & 6.0 \\
\hline $\begin{array}{l}\text { Total Kiejdahl } \\
\text { Nitrogen mgN/ } \\
\mathrm{dm}^{3}\end{array}$ & 11.7 & 7.9 & 23.7 & 10 & 26 & 8.6 & 6.8 & 9.86 & 8.4 \\
\hline Ptot. $\mathrm{mgP} / \mathrm{dm}^{3}$ & 0.54 & 0.42 & 3.1 & 1.1 & 0.46 & 0.32 & 0.61 & 0.72 & 0.28 \\
\hline
\end{tabular}

${ }^{a}$ The value of indicator is the average value obtained during last year before modernization and first year after modernization

bModernization of WWTP Warsaw "Czajka" was concerned on construction of installations enabling the removal of biogenic compounds from wastewater, biogas production, thermal treatment of sewage sludge with complete encapsulation of the process

${ }^{c}$ Modernization of WWTP Krakow "Plaszow" was focused on construction of a biological sewage treatment plant with a capacity of 328 thousand $\mathrm{m}^{3} / \mathrm{d}$, consisting of 5 biological reactors, 10 secondary settling tanks and a blower station, construction of a new sewage sludge treatment line, including thickening, methane fermentation, final dewatering, and production of heat from biogas

${ }^{\mathrm{d}}$ Modernization of WWTP Gdansk "Saur Neptun" was done for reduction of pollutant load in treated sewage, including total nitrogen value required below $10 \mathrm{mgN} / \mathrm{dm}^{3}$. After the modernization, the capacity of the treatment plant increased to $120,000 \mathrm{~m}^{3} / \mathrm{d}$

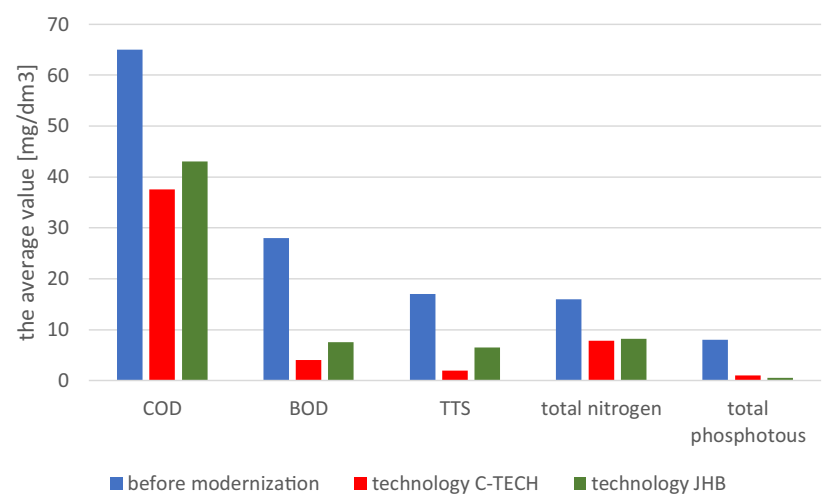

Fig. 4 The average values of WW quality indicators at WWTP Tychy before and after modernization with use of technology C-TECH and JHB (COD - chemical oxygen demand; BOD - biological oxygen demand, TSS - total suspended solids (Karło and Gieleciak 2019)

respectively and nitrogen- $51 \%$. However, the removal of phosphorous equal to $90 \%$ was obtained after treatment by JHB technology, the efficiency similar to that indicated in the literature. Installation of both technologies allowed for greater flexibility in conducting the processes.

The importance of using advanced methods for wastewater treatment were confirmed by Robescu and Presură (2017) after carbon footprint calculation in WWTP in Romania. They found that modernization of technology used at WWTP could cause a decrease in the value of GHG emission at $0.17 \mathrm{~kg} \mathrm{CO}_{2}$ eq per $\mathrm{m}^{3}$ treated wastewater or 32.33 [ $\mathrm{kg} \mathrm{CO}_{2} \mathrm{eq} / \mathrm{PE}$ and year].

\section{Biogas-a source of energy for public utilities}

Biogas produced in separate fermentation chambers (digesters) has recently become the most important energy "substrate" for wastewater treatment plants. According to the data of the Statistics Poland in 2019, there were 2,454 wastewater treatment plants in Poland using biological treatment processes and 817 wastewater treatment plants with increased removal of biogens, which could therefore be producers of treated biogas. In Poland, there are many commercial technological solutions for biogas production on the market, including CAMBI, SEEN TECHNOLOGIES, SYMBIONS. Currently, 140 WWTPs are equipped with the installations for the production of biogas, 112 plants are equipped with biogas-powered generators, and the total volume of digesters in all WWTPs is estimated at $800,000-900,000 \mathrm{~m}^{3}$ (Masłoń et al. 2020). It is estimated that from $1 \mathrm{~kg}$ of the removed organic suspension contained in sludge, it is possible to obtain from 0.75 to $1.12 \mathrm{~m}^{3}$ of biogas, with the methane production coefficient being from 80 to $377 \mathrm{~m}^{3} / \mathrm{Mg}$ organic dry matter, and the calorific value from 13 to $23 \mathrm{MJ} / \mathrm{m}^{3}$. After applying effective methods of upgrading, this value can be increased to $35.7 \mathrm{MJ} / \mathrm{m}^{3}$, thus close to that of natural gas. The upgrading of biogas leads to the creation of a fuel with a very high methane content (over $90 \%$ ), the so-called biomethane that can be successfully used for combustion in cogeneration devices. Unfortunately, the high investment costs of building the installation (both the digesters and the biogas refining system) and the common belief that in order for biogas production to be profitable, at 
least $10-12$ thousand $\mathrm{m}^{3}$ of sewage per day must flow to the treatment plant. Otherwise, the amount of produced methane will reduce the operating costs of the WWTP to such an extent that the cost of building an appropriate infrastructure will exceed possible profits, which makes the production of biogas meaningful only in large facilities. Another counterargument for the construction of such systems in wastewater treatment plants is the fact that only $50 \%$ of the organic substance is biodegradable in anaerobic conditions, and no one has any influence on the composition of wastewater, and thus its suitability for methane production (Grosser et al. 2020). Improving the efficiency of high-quality biogas production can be achieved by: (i) optimization of fermentation chambers operation; (ii) initial conditioning of sewage sludge; (iii) adequate biostimulation (e.g., dosing the chambers with appropriately selected additives (biochar, zeolites, activated carbon) and bioaugmentation (e.g., using modified microorganisms by genetic engineering methods); co-fermentation; (iv) development of new structures for fermentation chambers.

In turn, Sarpong and Gude (2020) identified the following possibilities for enhanced energy recovery: (i) by increasing the COD capture in primary treatment to enhance energy production; (ii) by replacing the activated sludge process with other less energy-intensive biological treatment technologies; and (iii) by increasing energy production from digesting supplementary feedstock in anaerobic co-digestion (AD) schemes. All these methods have their own advantages and disadvantages, but they undoubtedly improve the quantity and quality of the biogas produced. It is estimated that the preconditioning alone can increase the value of the biogas production factor in the range of $10-50 \%$. Another solution already used in Polish wastewater treatment plants is co-fermentation. High-energy waste is used, e.g., from the food and agricultural industry (sugar factories, fish and meat processing, fat plants, distilleries) or selectively collected biodegradable fraction of municipal waste. A good example is the WWTP Tychy, where the surplus of electricity and heat contributed to the investment in the Water Park Tychy. Co-fermentation is carried out in two separate fermentation chambers with a volume of $5500 \mathrm{~m}^{3}$ each. Biodegradable waste (including waste whey) is mainly used as substrates for co-fermentation, and the continuous optimization of the process has contributed to a gradual increase in the efficiency of biogas production-from almost 2.5 million $\mathrm{m}^{3}$ in 2009 to nearly 6.5 million $\mathrm{m}^{3}$ in 2018 . High energy production of the company's own RES (renewable energy source) allowed the company to leave the standard scope of the company's activity and construction of Water Park Tychy, powered exclusively with energy coming from this source. In order to cover the company's and of the water park demand the Tychy wastewater treatment plant has to produce between 16 thousand $\mathrm{m}^{3}$ (in summer) and 19 thousand $\mathrm{m}^{3}$ per day (winter) of biogas. Due to the highly efficient energy economy during the co-digestion process, the average volume of biogas produced in the WWTP Tychy in 2017 was equal 17.4 thousand $\mathrm{m}^{3}$ per day (Karło and Gieleciak 2019). In comparison, the WWTP Lodz (the second largest WWTP in Poland) produced 23 thousand $\mathrm{m}^{3}$ per day in 2019 (data from WWTP).

\section{Energy from WWTP}

Wastewater is usually considered as a good energy source. In WWTP, electricity and/or heat can be produced from: (i) cogeneration and/or biogas combustion systems, (ii) chemical oxidation of sewage sludge, (iii) thermal treatment of sewage sludge, (iv) heat of treated sewage, and (v) additional installations-ground heat pumps or photovoltaic panels. Electricity generated by the cogeneration system is used to cover the plant's own needs, and the surplus of electricity is transferred to the public power grid. In the case of a biogas engine, waste heat from the engine cooling system and heat from the exhaust gas system are generated in wastewater treatment plants. This heat is transferred in the engine cooling water stream and used for heating purposes. It is estimated that under Polish conditions the investment costs can pay off even after 9 months.

According to Statistics Poland in 2018, there were approximately $72 \mathrm{MW}$ of electric power using biogas from sewage treatment plants. The above generation capacity made it possible to generate approximately $337 \mathrm{GWh}$ of electricity from treated biogas. Data illustrating the scale of electricity production in selected sewage treatment plants in Poland are presented in Table 2. Eleven WWTPs produce approximately $34 \%$ of the total volume of approximately $337 \mathrm{GWh}$ of electricity from biogas in Poland. The potential

Table 2 Average annual energy production from biogas at WWTPs in Poland (Biogas in Poland, Raport 2020)

\begin{tabular}{ll}
\hline WWTP name (city) & $\begin{array}{l}\text { Estimated average annual level } \\
\text { of electricity production [GWh] }\end{array}$ \\
\hline Czajka (Warsaw) & 29.6 \\
Lodz & 19.5 \\
Tychy & 14.3 \\
Gdansk-Wschod & 12.7 \\
Poznan-Centralna & 12.0 \\
Hajdow Lublin & 10.0 \\
Poznan-Lewobrzezna & 4.2 \\
Poludnie & 3.6 \\
Pruszkow & 3.5 \\
Krosno & 2.6 \\
Krakow-Plaszow & 1.0 \\
Total & $\mathbf{1 1 3}$ \\
\hline
\end{tabular}


of producing electricity from biogas in WWTPs in Poland can be estimated at approximately $700-850 \mathrm{GWh}$ per year (Raport, 2020). For comparison, in 2018, the EU-28 primary energy production from sewage sludge gas amounted to 1,509 metric kilotons of oil equivalent (Statista 2021).

As Macintosh et al. described (2019), the Grüneck WWTP, operated in Germany, increased energy self-sufficiency by $24 \%$ (from 64 to $88 \%$ ) through reducing energy consumption with aeration upgrades (8\% increase) and increasing energy production with food waste co-digestion (16\% increase). The plant-wide analysis indicated that the aeration upgrades did not affect effluent quality; however, codigesting food waste at $20 \%$ additional organic load caused some minor downstream impacts including reduced dewaterability, fluctuating biogas quality, and solids accumulation.

Dried sewage sludge is also a source of renewable energy and is used, among others, in cement plants as alternative fuels. However, according to the Cement Producers Association in 2015, the share of sewage sludge in the total amount of alternative fuels used in the technological process (mainly for the production of clinker) was only $0.7 \%$.

\section{Energy self-sufficiency}

Wastewater treatment plants is a high-energy-consuming facility in terms of the necessity for optimizing several technological processes during wastewater as well as sewage sludge treatment. The gain of the balance between the energy, heat production and consumption is one of the most significant challenges posed by the idea of the circular economy. At the WWTP, on the one hand, the energy balance is connected with production of biogas and energy from its own renewable energy source and its increase in quality with the usage of the biogas purification station. On the other hand, there is increased energy demand resulting from the need to adapt wastewater treatment processes and sludge treatment to increasingly higher standards for the removal of pollutants. To minimize the need for energy, diagnoses of the most energy-consuming locations in technological processes and their modernization or liquidation has been done. Usually, the processes used in the third stage of wastewater treatment (UV lamps, ozone generators, pumps, etc.) are considered the most energy-consuming, followed by biological and mechanical treatment. According to Wróblewski and Heidrich (2017), an electricity consumption in the Polish WWTPs ranges from 0.45 to $1.29 \mathrm{kWh} / \mathrm{m}^{3}$, with the average value equal to $0.84 \mathrm{kWh} / \mathrm{m}^{3}$. The similar average values of energy intensity index for WWTPs can be found in the report of the Chamber of Commerce "Polish water-works"$0.77 \mathrm{kWh} / \mathrm{m}^{3}$ (Benchmarking 2019) and the study of Gromiec (2016), who makes the need for energy dependency on the size of the treatment plant: $0.84 \mathrm{kWh} / \mathrm{m} 3$ for smaller facilities (less than 100 thousand inhabitants) and $0.62 \mathrm{kWh} / \mathrm{m} 3$ for bigger ones (more than 100 thousand inhabitants). The WWTP Tychy produces electricity and heat in the process of cogeneration of biogas produced from the co-fermentation of sewage sludge and biodegradable waste, which are obtained from external suppliers from various branches of industry. The approach based on industrial symbiosis has allowed for the achievement of very good energy efficiency indices. Already in 2010, energy produced from biogas covered the demand of the treatment plant up to $99.16 \%$, and since 2012 , surpluses have been regularly obtained. The red line shows that the number of investments in innovative technological solutions and continuous optimization of the co-fermentation process have contributed to achieving the energy self-sufficiency of the treatment plant at the level of $200 \%$. Thanks to the energy symbiosis of both facilities, it was possible to entirely cover their demand for electricity and heat from biogas cogeneration arising in a sewage treatment plant, and in addition, surplus energy is sold to the grid (PEC/TAURON), which generates additional profits (Karło and Gieleciak 2019). Since 2006, when cogeneration units at the WWTP began working, by the end of 2018, $78867.576 \mathrm{MWh}$ of electricity was produced from biogas. To produce an equivalent amount of energy, a conventional power plant would use $37,408 \mathrm{Mg}$ of heavy coal. Considering the thermal energy generated in cogeneration, the amount of this raw material would increase to $76,801 \mathrm{Mg}$ (assuming efficiency of the plant at an average level of 33\%, heating plant efficiency at an average level of $42 \%$ and a calorific value of coal equal to $23 \mathrm{GJ} / \mathrm{Mg}$ ). The potential of industrial symbiosis for improving energy efficiency is not only the implementation of co-fermentation (with use of high-energy waste) but also the co-gasification of sewage sludge and municipal waste (including waste biomass classified as other and alternative SRF fuels) with the concept of waste to energy. Moreover, the modernization of the most energy-consuming devices and the optimalization of some processes also bring significant energy savings. In turn, at the WWTP Klimzowiec (Silesia region) identified the most energy-consuming devices: (i) internal recirculation (23.33\%); (ii) air blowers (20.85\%); (iii) pump station (10.84\%); (iv) aeration of biological chambers $(9.11 \%)$; (v) external recirculation $(6.87 \%)$; and (vi) mechanical wastewater treatment (5.86\%). According to the fact that the most energy-consuming process was nitrogen removal (aeration, internal recirculation), it was therefore decided to change the method of process control (Table 3 ).

As shown in Table 4, modernization of most energy-consuming devices at the WWTP Tychy did allow for significant reduction of energy consumption and substantial savings per year.

On the other hand, the use of existing areas of sewage treatment plants for the construction of photovoltaic farms may undoubtedly improve the energy efficiency of the 
Table 3 Optimalization of the nitrogen removal process for energy savings and process efficiency at the WWTP Klimzowiec as a modernization of biological chambers (aeration, internal recirculation)

\begin{tabular}{|c|c|c|c|}
\hline Before modernization & \multicolumn{3}{|c|}{ After modernization } \\
\hline \multicolumn{4}{|l|}{ Aeration control: } \\
\hline To obtain the desired oxygen concentration & \multicolumn{3}{|c|}{$\begin{array}{l}\text { On the concentration of } \mathrm{N}-\mathrm{NH} 4 \text { at the outlet of the } \\
\text { aeration chambers }\end{array}$} \\
\hline \multicolumn{4}{|l|}{ Recirculation control: } \\
\hline $\begin{array}{l}\text { A given percentage of the amount of incoming } \\
\text { sewage }\end{array}$ & \multicolumn{3}{|c|}{$\mathrm{N}-\mathrm{NO}_{3}$ concentration at the outlet of aeration chambers } \\
\hline Modernization & & $\begin{array}{l}\text { Energy consumption } \\
\text { decrease }(\%)\end{array}$ & $\begin{array}{l}\text { Savings per } \\
\text { year (MWh) }\end{array}$ \\
\hline \multicolumn{2}{|l|}{ Modernization of the main sewage pumping station } & 47 & 241 \\
\hline \multicolumn{2}{|l|}{ High-performance interior lighting } & 41 & 3 \\
\hline \multicolumn{2}{|l|}{ Modernization of aeration of biological chambers } & 29 & 1223 \\
\hline \multicolumn{2}{|l|}{ Modernization of recirculation the pumping station } & 78 & 512 \\
\hline \multicolumn{2}{|c|}{$\begin{array}{l}\text { Replacement of lighting fittings for external illumination of } \\
\text { the WWTP }\end{array}$} & 61.5 & 58 \\
\hline
\end{tabular}

Table 4 The changes in energy consumption after modernization of high-energyconsuming processes at the Tychy WWTP (Gieleciak 2018) is not deteriorated. In 2014, the directive was assessed as part of the "ex post evaluation of certain waste stream directives." The evaluation revealed a number of shortcomings, largely due to the fact that the regulation was adopted 35 years ago and does not fully meet actual problems connected with the presence of new pollutants in the environment. In Poland, the use of sewage sludge is regulated by the Regulation of the Minister of the Environment from 2015. According to the data of the Statistics Poland in 2019, approximately $25 \%$ of sewage sludge is used in agriculture and for land reclamation in Poland. For comparison, in Germany, sewage sludge compost was used for agriculture purposes and in Italy as fertilizer for agriculture $(95 \%)$, fertilizer for horticulture $(3 \%)$, and fertilizer for fruit growing (2\%), (Corden et al. 2019).

The processing of sludge from waste to product can be difficult, requiring additional installations and many bureaucratic activities. However, reclassification of the waste allows for a product to be obtained that can be marketed. From sewage sludge, promoting agents such as organic fertilizers, organic-mineral fertilizers or plant growth improvers may be produced. All of them require certification and fulfillment of the requirements specified in the relevant regulations of the Ministry of Agriculture.

Composting of sewage sludge requires mixing it with a structure-forming material, e.g., straw (corn, wheat, from energy crops-miscanthus), sawdust and/or other waste, e.g., grass or organic fraction of municipal waste. However, it should be remembered that the compost remains waste after the process, unless it meets the legal requirements (Table 5). In Poland, the compost produced can be marketed as an organic fertilizer or as an agent supporting the and that the quality of the soil, surface and groundwater 
Table 5 The selected requirements of compost quality according Polish and German law

\begin{tabular}{|c|c|c|}
\hline Parameter & Polish law $^{\mathrm{a}}$ & German law $^{\mathrm{b}}$ \\
\hline chromium $\mathrm{Cr}\left[\mathrm{mgkg}^{-1}\right.$ dry matter $]$ & 100 & 100 \\
\hline cadmium $\mathrm{Cd}\left[\mathrm{mgkg}^{-1}\right.$ dry matter] & 5 & 1.5 \\
\hline nickel Ni $\left[\mathrm{mgkg}^{-1}\right.$ dry matter] & 60 & 50 \\
\hline lead $\mathrm{Pb}\left[\mathrm{mgkg}^{-1}\right.$ dry matter $]$ & 140 & 150 \\
\hline mercury $\mathrm{Hg}\left[\mathrm{mgkg}^{-1}\right.$ dry matter] & 2 & 1.0 \\
\hline zinc $\mathrm{Zn}\left[\mathrm{mgkg}^{-1}\right.$ dry matter] & - & 400 \\
\hline cuprum $\mathrm{Cu}\left[\mathrm{mgkg}^{-1}\right.$ dry matter $]$ & - & 100 \\
\hline organic matter [dry matter] & At least $30 \%$ & At least $15 \%$ \\
\hline $\mathrm{N}_{\text {tot. }}[$ dry matter] & At least $0.3 \%$ & Declaration \\
\hline $\mathrm{P}_{\text {tot }}$ as $\mathrm{P}_{2} \mathrm{O}_{5}$ [dry matter] & At least $0.2 \%$ & Declaration \\
\hline $\mathrm{K}$ as $\mathrm{K}_{2} \mathrm{O}$ [dry matter] & At least $0.2 \%$ & Declaration \\
\hline $\begin{array}{l}\text { Ascaris sp., Trichuris sp. Toxocara } \\
\text { sp. live eggs }\left[\mathrm{kg}^{-1} \text { dry matter }\right]\end{array}$ & Not detected & - \\
\hline Salmonella $\mathrm{sp} .\left[\mathrm{kg}^{-1}\right.$ dry matter $]$ & Not detected & Not detected \\
\hline
\end{tabular}

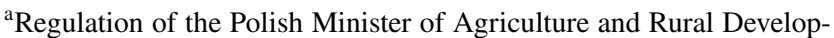
ment of June 18 (2008) on the implementation of certain provisions of the Act on fertilizers and fertilization

${ }^{b}$ Quality requirements for compost according to the German Institute for Quality Assurance and Certification (RAL) quality standard "RAL-GZ 251"

cultivation of plants, in the form of: a soil conditioner (soil improver), a growth stimulant, or a cultivation medium.

In practice, most often composting facilities or WWTPs apply for the status of an organic fertilizer for nutrient-rich composts or a soil conditioner for other composts. Regardless of the method of biomatter recovery and inclusion of sewage sludge in the biological cycle, the WWTP should choose not only the financial outlay to purchase and implement the appropriate technology, but also R\&D work to obtain the appropriate product quality. It is estimated that in Poland more than 100 WWTPs in Poland produce compost at high quality. Some authors suggest, however, that not every substrate added to waste during composting process will produce good quality compost (Maroušek et al. 2016). The European Compost Network (ECN) noted that EU28 produced 12.1-16.2 million tonnes of compost. However, EU production of sewage sludge compost is much lower at the level 0.8 million tonnes (Corden et al. 2019).

In recent years, sludge treatment methods leading to the production of organic and mineral fertilizers have slowly started to gain importance. Within the Polish market, fertilizer products such as ORTWED, a Danish company fertilizer "Biowap" (Decision 91/04; July 13, 2004) OrCal ${ }^{\circledR}$ fertilizer (Decision No. 183/07 Mark HORnn-4077-2 / 07 of 2007); "Gramed" fertilizer with Decision No. $280 / 11$ issued in 2011, "Klonex" fertilizer with Decision No. G-463/14 of 2014; and the "Oskar"" fertilizer by OMEGA (Decision 289/12 on February 16, 2012).
In order to use of this type as a fertilizer, a significant amount of inorganic substrates should be added. These are calcium compounds, sulfuric acid, magnesium, and potassium compounds, or fly ash from the combustion of hard coal or brown coal. The most frequently used solutions are based on the introduction of a significant amount of quicklime (containing active calcium oxide $\mathrm{CaO}$ ), which is a traditional hygienizing agent for sewage sludge. The amount of heat generated by the strong exothermic reaction is directly proportional to the amount of water needed for evaporation and the amount of added quicklime $\mathrm{CaO}$. According to fertilizer manufacturers, the resulting slaked lime can react at a temperature elevated to $135-140{ }^{\circ} \mathrm{C}$ with the presence of, for example, amorphous silicic acid or aluminum compounds present in the sewage sludge.

There are a few wastewater treatment plants that are also certified to produce a soil conditioner from sewage sludge. The WWTP Lubań, as a result of the autothermal aerobic (thermophilic) stabilization of sludge in ATSO reactors and their dehydration, obtained a permit in 2020 to introduce the NATUR-GLEB product. NATUR-GLEB has an approval issued by the Decision of the Ministry of Agriculture and Rural Development No.G-927/20 of April 21, 2020.

On June 25, 2019, a new Regulation (EU) 2019/1009 of the European Parliament and of the Council of 5 June 2019 laying down rules on the making available on the market of EU fertilizing products and amending Regulations (EC) No 1069/2009 and (EC) No 1107/2009 and repealing Regulation (EC) No 2003/2003 was published. Part II of this Regulation prohibits the use of sewage sludge as ingredients in the production of EU fertilizing products.

\section{Management and decision methodology}

According to linear economy, the processing capacity has been the leading factor in the design the wastewater treatment plants as a main value related to the supply and effluent requirements. The $\mathrm{CE}$ totally changed the approach to WWTP. The facility become a source of not only water but also energy, raw materials or substrates. WWTP, as a resource plant, is driven by local conditions and drivers. It should consist of a business case philosophy that balances resource supply, sustainable development and financial soundness. The products should be returned at the local market (for example heat), regional market (energy, bioproducts), national or global market (raw materials). Hence, the WWTP as production site during the planning phase of a large-scale renovation or new construction has to take into consideration not only the development of technology or social and environmental requirements, but also legislation and economy. Zarei (2020) mentioned that there are many relationships between infrastructures, complex 
economic-environmental-social-political circumstances, and reuse limits. The author identifies three different approaches: (i) the best available technology, (ii) the decision support system, and (iii) risk management. According to IWA (2017), cities aiming to meet sustainable development goals (SDGs) are establishing ambitious targets to reuse and find opportunities to address water security, public health and socioeconomic development for the wastewater sector (Table 6). The report indicates that decentralization leads to different technologies used in wastewater treatment plants, and that environmental, economic, and social conditions force the direction of changes (Table 6).

There are several steps of a decision tree that when used in combination can result in an optimal model for the circular economy concept. The key points include: (i) the need to recover resources; the necessity of recovering nutrient, water, and energy should be balanced with the cost of technology implementation. Due to the fact that the costs may even make these options non-viable in the short term, it is very important to identify financial limitations versus sustainability goals in the long term; (ii) resource demands; product necessity should be identified at a local and more general level, its quality, frequency of use, distribution of the end product and storage requirements; (iii) technology/ asset requirements; (iv) financial factors; and (v) risk/benefits factors.

Zarei (2020) notes that in the case of recovering energy from wastewater, it could be achieved by some basic actions and the use of a system decision tree: (i) engaging public support; (ii) establishing new policies; (iii) choosing the most applicable type a wastewater treatment; (iv) developing a national, regional and local action plan; (v) coordinating investments and financing; (vi) applying the quality criteria to end product; (vii) evaluating the most cost-effective

Table 6 Comparison of a reuse opportunities at different WWTP's, according to IWA (2017)

\begin{tabular}{|c|c|c|c|c|c|c|c|}
\hline City & Population & $\begin{array}{l}\text { Sewer service } \\
\text { coverage }(\%)\end{array}$ & $\begin{array}{l}\text { Treated wastewa- } \\
\text { ter currently } \\
\text { reused }(\%)\end{array}$ & $\begin{array}{l}\text { Potential to } \\
\text { reduce emissions } \\
\left(\mathrm{Mg} \mathrm{CO}_{2} \text { e/year }\right)\end{array}$ & $\begin{array}{l}\text { Nutrient recov- } \\
\text { ery }\end{array}$ & Energy recovery & Specific goals \\
\hline Aqaba (Jordan) & 194000 & 90 & 69 & -81000 & $\begin{array}{l}\text { No fertilizers } \\
\text { recovery }\end{array}$ & $100 \%$ & $\begin{array}{l}\text { Zero sewage dis- } \\
\text { charge policy }\end{array}$ \\
\hline $\begin{array}{l}\text { Bangkok (Thai- } \\
\text { land) }\end{array}$ & 5.6 million & 40 & 5 & -638000 & $\begin{array}{l}\text { Yes directly as } \\
\text { sewage sludge } \\
\text { or compost }\end{array}$ & $62 \%$ & $\begin{array}{l}\text { Sludge as a } \\
\text { resource and a } \\
\text { valuable eco- } \\
\text { nomic good }\end{array}$ \\
\hline Beijing (China) & 21.6 million & 95 & 15 & -1044000 & Yes & $45 \%$ & $\begin{array}{l}\text { Investing in } \\
\text { "mega" infra- } \\
\text { structure to } \\
\text { reduce pollution } \\
\text { from increasing } \\
\text { wastewater flows }\end{array}$ \\
\hline Chennai (India) & 8.5 million & 100 & 49 & -235000 & No & $77 \%$ & $\begin{array}{l}\text { Service standards } \\
\text { setting the scene } \\
\text { for accelerated } \\
\text { wastewater reuse } \\
\text { and the "Zero } \\
\text { Water Discharge } \\
\text { in Chennai" }\end{array}$ \\
\hline $\begin{array}{l}\text { Durban (South } \\
\text { Africa) }\end{array}$ & 3.7 million & 16 & 44 & -438000 & Yes & $8 \%$ & $\begin{array}{l}\text { Wastewater reuse } \\
\text { as an economic } \\
\text { good }\end{array}$ \\
\hline $\begin{array}{l}\text { Kampala } \\
\text { (Uganda) }\end{array}$ & 1.5 million & 40 & 100 & -114000 & Yes & $227,000 \mathrm{KWh} / \mathrm{y}$ & $\begin{array}{l}\text { Work towards } \\
\text { increased treat- } \\
\text { ment and reuse } \\
\text { of wastewater } \\
\text { and sewage } \\
\text { sludge, }\end{array}$ \\
\hline Lima (Peru) & 10 million & 83 & 5 & -652000 & No & Low & Wastewater reuse \\
\hline $\begin{array}{l}\text { Manila (Philip- } \\
\text { pines) }\end{array}$ & 12.2 million & 15 & 0 & -1680000 & No & Low & $\begin{array}{l}\text { Privatization of the } \\
\text { water sector }\end{array}$ \\
\hline
\end{tabular}

aZero sewage discharge policy is addressed by: (1) seizing the opportunity to supplement the city's water resources with fit for purpose reuse water that is then sold; (2) recovering energy from wastewater to reduce the operating costs; (3) drawing in private sector financing based on shared interests for an attractive and liveable city 
potential wastewater reuse; (viii) building suitable infrastructures; and (ix) applying integrated schemes for wastewater treatment and reuse. Many WWTPs have invested in new technologies to better control processes and use less electricity, with non- $\mathrm{CO}_{2}$ greenhouse gas emissions decreasing by 20\% between 2005 and 2017 (EEA 2020b). The European Environmental Agency identified new challenges for European wastewater sector such as: climate change and the presence of hazardous substances (EEA 2020b; Fig. 5). Despite significant improvements in recent years in wastewater treatment in urban areas, finding space to install new treatment plants or upgrade existing ones can be a challenge. Moreover, there can be public opposition to building facilities near residential areas, owing to noise and odor concerns (EEA 2020b)

Unfortunately, in Poland, there are only a few WWTPs where the holistic approach to the circular economy concept is developing. A good example is the Regional Centre for Water and Wastewater Management Co. in Tychy, which has for many years effectively implemented the assumptions of intelligent and sustainable development as a part of the "circular economy" model. RCWWM Tychy as an WWTP owner has technical and technological facilities for cleaning up over 15 million $\mathrm{m} 3$ of municipal sewage during the year, both from residents and from industrial plants. The company based the concept on three basic pillars-ecology, economics and education improve following rules (Gieleciak 2018): (i) no emission or minimal emission to the environment; (ii) minimization of waste production; (iii) energy self-sufficiency; (iv) rationalization of water usage; and (v) optimalization of influent and rationalization of technological processes. In this way, the concept of the intelligent (smart) city of SymbioTychy was created by the Centre based on the free flow of energy within the urban framework as an effect of supplying renewable energy from the municipal infrastructure and in accordance with the principles of sustainable development (Fig. 6), (Karło and Gieleciak, 2018) The Centre is one of the first Polish communal companies
KNOWN CHALLENGES

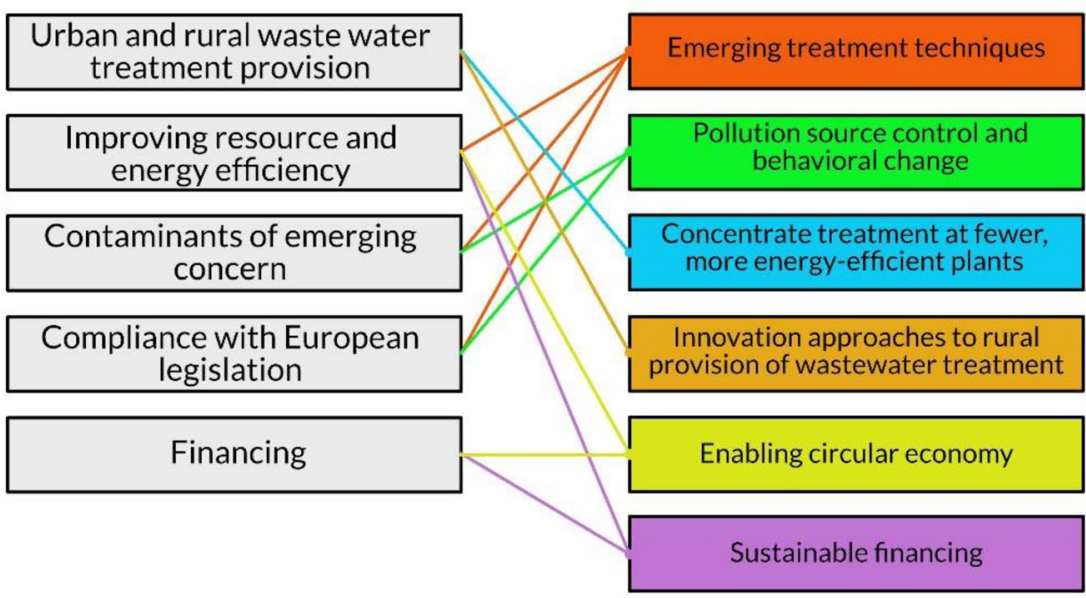

\section{THE OPPORTUNITIES}

Fig. 5 Challenges, solutions and opportunities in the wastewater treatment management ( source: EEA 2020b, modified)

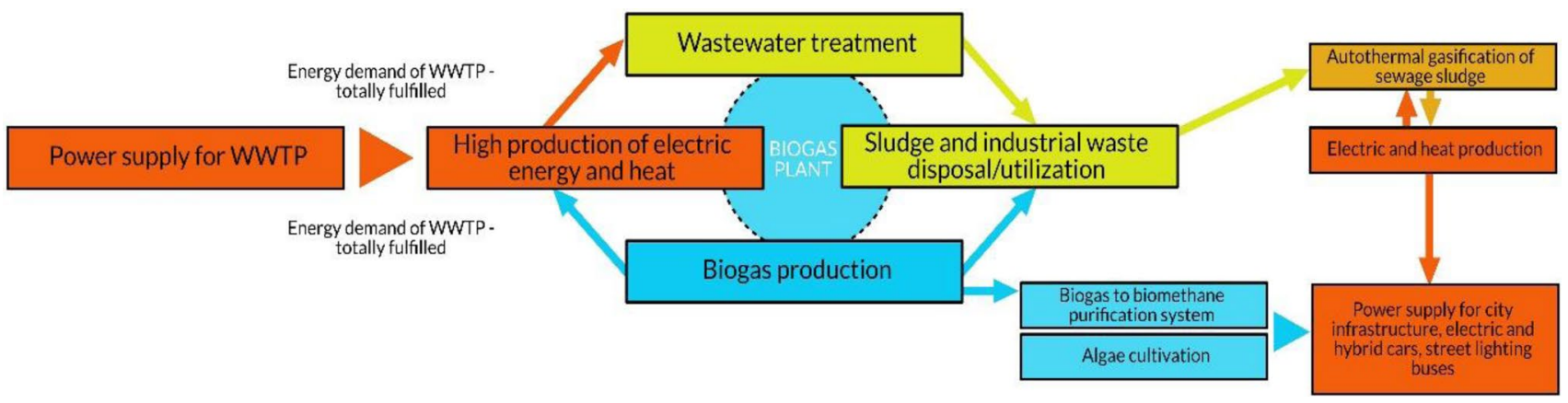

Fig. 6 The conception of smart city SymbioTychy - cooperation among wastewater treatment (Karło and Gieleciak 2018), modified 
to introduce elements of a circular economy in a practical way at WWTP, optimizing a company's own technological processes and creating a long-term development strategy according to $\mathrm{CE}$.

In turn, at WWTP Krakow Plaszow, the Integrated Energy Efficiency System has been introduced (Małka et al. 2017). The system is designed to provide and aggregate the operating parameters of devices and environmental parameters - rainfall or water levels. The set of correlated and processed data collected in this manner is to help the staff make decisions about the selection of the best possible setting parameters of actuators in the context of optimizing electricity consumption under specific conditions. The system was built so that IT and communication solutions are compatible with the standards adopted and used in the WWTP. Additionally, due to the security of the system, it works in a virtualized environment. The system allowed for a decrease in the average energy consumption by $12 \%$. An example was the management of three pumps with a capacity of $160 \mathrm{~kW}$ and seven pumps with a capacity of $132 \mathrm{~kW}$. The introduced modifications resulted in an annual savings of approximately $1000 \mathrm{MWh}$ in electricity consumption. In the case of blowers, a change in the method of controlling the operation of reactors allowed for savings in electricity consumption at the level of $20 \%$. The annual savings amounted to another 2,100 MWh (Małka et al. 2017).

\section{Conclusion}

The transformation of a linear economy to a circular economy model should be multidirectional, industrialized and organized based on the search for places that are tangible in many areas of the economy and allow for the completion of niches and current needs according to sustainable development. The term "wastewater treatment plant" is associated more with waste disposal and utilization rather than resource opportunities. However, a WWTP is slowly becoming an important part of the smart city and is changing into important producers of water, energy, nutrients and other supplies (metals, humic acids, enzymes, polysaccharides, and many others). Such a model developed at WWTP should reconcile technology requirements, financial factors and risks/benefits which promote all recovery opportunities within the local community. The novelty of such an approach was verified during the introduction of the bioeconomy conception into a business model at the facility and shows possible economical, ecological and social benefits. Hence, the implementation of the idea, "think globally, do locally" could be a very important point at the trial of introduction of a circular economy at the infrastructure of water and wastewater management. The implementation of the global rules of a circular economy concept at the regional level could be possible due to cooperation with local entrepreneurs (for supplying high-energy waste to improve methane fermentation efficiency), local government (water park creation and building) and society (conducting educational classes, environmental activities, modernizing the water supply network). The wastewater treatment plant is less of a necessary investment but is usually located on the outskirts of cities due to odor nuisance and the negative impact on the environment.

Acknowledgements The publishing was made possible due to the project financed by the Polish National Agency for Academic Exchange the EnviSafeBioC project - contract No PPI/APM/2018/1/00029/U/001 and the statute subvention of Czestochowa University of Technology, Faculty of Infrastructure and Environment.

Open Access This article is licensed under a Creative Commons Attribution 4.0 International License, which permits use, sharing, adaptation, distribution and reproduction in any medium or format, as long as you give appropriate credit to the original author(s) and the source, provide a link to the Creative Commons licence, and indicate if changes were made. The images or other third party material in this article are included in the article's Creative Commons licence, unless indicated otherwise in a credit line to the material. If material is not included in the article's Creative Commons licence and your intended use is not permitted by statutory regulation or exceeds the permitted use, you will need to obtain permission directly from the copyright holder. To view a copy of this licence, visit http://creativecommons.org/licenses/by/4.0/.

\section{References}

Benchmarking (2019) The results of Water and Sewage Enterprises in Poland. Chamber of Commerce "Polish Water", [in Polish], https://igwp.org.pl/index.php/nasza-aktywnosc/benchmarking/ 1240-materialy-benchmarking-2019, Accessed 05/06/2021

Biogas in Poland - Report 2020 (2020), Biomasa Journal [in Polish], https://magazynbiomasa.pl/biogaz-w-polsce-raport-2020-dzispremiera-publikacji/ Accessed 29/03/2021

Bianchini A, Bonfiglioli L, Pellegrini M, Saccani C (2016) Sewage sludge management in Europe: a critical analysis of data quality. Int J Environ Waste Manage 18(3):226-238

Common Implementation Strategy for the Water Framework Directive and the Floods Directive - Guidelines on Integrating Water Reuse into Water Planning and Management in the context of the WFD (2016), https://ec.europa.eu/environment/water/pdf/Guidelines_ on_water_reuse.pdf, Accessed 05/06/2021

Communication from the Commission to the European Parliament, the Council, the European Economic and Social Committee and the Committee of the Regions "Closing the Loop - an EU action plan for the circular economy. The European Commission, Brussels, (2015), https://eur-lex.europa.eu/legal-content/EN/TXT/?uri= CELEX\%3A52015DC0614, Accessed 05/06/2021

Corden C, Bougas K, Cunningham E, Tyrer D, Kreißig J, Zett E, Gamero E, Wildey R, Crookes M (2019) Digestate and compost as fertilisers: Risk assessment and risk management options. Final Report, Wood Environment \& Infrastructure Solutions UK Limited - February 2019, https://ec.europa.eu/environment/ chemicals/reach/pdf $/ 40039 \% 20$ Digestate $\% 20$ and $\% 20 \mathrm{Com}$ post\%20RMOA\%20-\%20Final\%20report\%20i2_20190208.pdf , Accessed 29/03/2021 
EEA, 2020a, Urban wastewater treatment in Europe. Accessed $29 / 03 / 2021$

EEA, 2020b, Urban wastewater treatment for 21 st century challenges - European Environment Agency (europa.eu), Accessed $29 / 03 / 2021$

EU-level instruments on Water Reuse. Final Report to support the Commission's Impact Assessment. Amec Foster Wheeler Environment \& Infrastructure UK Ltd, IEEP, ACTeon, IMDEA and NTUA (2016)

Gherghel A, Teodosiu C, De Gisi S (2019) A review on wastewater sludge valorisation and its challenges in the context of circular economy. J Clean Prod 228:244-263

Gieleciak Z (2018) Wastewater treatment plant in XXI century as a one of the main elements of bioeconomy concept [in Polish]. Conference materials from ENVICON - XXII International Congress of Environmental Protection. Warsaw, Poland, 2018 [materials in printed form]

Gromiec M (2016) New role of water-sewage management in development of cities and limiting climate change. Materials from II Forum of Environmental Protection. Ecology as stimulator of cities development, Warsaw, 15-16.02.2016, https://water.put. poznan.pl/images/fullpapers2016/PRAWO_ZARZADZANIE_ EKONOMIA/69 WODA 2016_WODA 1_10062016.pdf

Grosser A, Neczaj E, Jasińska A, Celary P (2020) The influence of grease trap sludge sterilization on the performance of anaerobic co-digestion of sewage sludge. Renewable Energy. https://doi.org/ 10.1016/j.renene.2020.07.108

Gu Y, Li Y, Li X, Luo P, Wang H, Wang X, Wu J, Li F (2017) Energy self-sufficient wastewater treatment plants: feasibilities and challenges. Energy Procedia 105:3741-3751

Hagenvoort J, Ortega-Reig M, Botella S, García C, de Luis A, PalauSalvador G (2019) Reusing Treated Waste-Water from a Circular Economy Perspective-The Case of the Real Acequia de Moncada in Valencia (Spain), Water 11, 1830; doi:https://doi.org/10. 3390/w11091830

International Water Association (2018) The Reuse Opportunity, Wastewater Report 2018, pp. 23, iwa-network.org, Accessed $29 / 03 / 2021$

Karło A, Gieleciak Z (2018) Municipal sewage treatment plant as part of circular economy [in Polish]. Gas, Water and Sanitary Technique (5): 178-180, http://yadda.icm.edu.pl/baztech/eleme nt/bwmeta1.element.baztech-c696090d-2004-46f8-b42f-6b5cb caee 512

Karło A. Gieleciak Z (2019) Energetic symbiosis of wastewater treatment plant and Water Park Tychy as an example of innovative approach of using renewable energy sources [in Polish]. Gas, Water and Sanitary Technique (1):18-21, https://yadda.icm.edu. pl/baztech/element/bwmeta1.element.baztech-e80c8720-2b0745fd-9fd2-e47c124eb808

Kehrein P, van Loosdrecht M, Osseweijer P, Garfí M, Dewulf J, Posada J (2020) A critical review of resource recovery from municipal wastewater treatment plants-market supply potentials, technologies and bottlenecks. Environ Sci Water Res Technol 6:877-910

Konopka D (2019) Use of wastewater for cooling heat and power plants [in Polish]. Wodociągi i Kanalizacja 07/08, http://sklep.abrys.pl/ pl/p/e-wydanie-Wodociagi-Kanalizacja-0708-2019/1241

Macintosh C, Astals S, Sembera C, Ertl A, Drewes JE, Jensen PD, Koch K (2019) Successful strategies for increasing energy selfsufficiency at Grüneck wastewater treatment plant in Germany by food waste co-digestion and improved aeration. Appl Energy 242:797-808

Małka P, Uhl T, Klapyta J, Langer R (2017) Integrated Energy Efficiency System as a significant element increasing the reliability of water supply and sewage systems [in Polish], Gas, Water and Sanitary Technique, 4, 154-156, http://yadda.icm.edu.pl/baztech/ element/bwmeta1.element.baztech-5d1d931b-4cb4-4727-a5ded00e15b12314

Maroušek J, Hašková S, Zeman R, Žák J, Vaníčková R, Maroušková A, Váchal J, Myšková K (2016) Polemics on Ethical Aspects in the Compost Business. Sci Eng Ethics 22(2):581-590. https://doi. org/10.1007/s11948-015-9664-y

Maroušek J, Kolář L, Strunecký O, Kopecký M, Bartoš P, Maroušková A, Cudlínová E, Konvalina P, Šoch M, Moudrý (Jr) J, Vaníčková R, Vrbka J, (2020) Modified biochars present an economic challenge to phosphate management in wastewater treatment plants. J Cleaner Prod V 272:123015. https://doi.org/10.1016/j.jclepro. 2020.123015

Masłoń A, Czarnota J, Szaja A, Szulżyk-Cieplak J, Łagód G (2020) The enhancement of energy efficiency in a wastewater treatment plant through sustainable biogas use: case study from poland. Energies 13(22):6056. https://doi.org/10.3390/en13226056

Montwedi M, Munyaradzi M, Pinoy L, Dutta A, Ikumi DS, Motoasca E, Van der Bruggen B (2021) Resource recovery from and management of wastewater in rural South Africa: Possibilities and practices. J Water Process Eng 40:101978. https://doi.org/10. 1016/j.jwpe.2021.101978

Neczaj E, Grosser A (2018) Circular Economy in Wastewater Treatment Plant-Challenges and Barriers, Proceedings, 2: 614, https://doi.org/10.3390/proceedings2110614

Qui J, Wang H, Wang K, Yu G, Ke B, Yu H-Q, Ren H, Zheng X, Li J, Li W-W, Gao S, Gong H (2019) Municipal wastewater treatment in China: Development history and future perspectives. Front Environ Sci Eng 13(6):88

Polish Statistical Office, Environment, 2019, Warsaw, 2020, https:// stat.gov.pl/, Accessed 29/03/2021

Pott R, Johnstone-Robertson M, Verster B, Rumjeet, S, Nkadimeng L, Raper T, Rademeyer S, Harrison STL (2018) Wastewater Biorefineries: Integrating Water Treatment and Value Recovery, In: Walter Leal Filho and Dinesh Surroop Editors The Nexus: Energy, Environment and Climate Change, Springer International Publishing AG, pp. 289-304

Regulation of the Minister of Agriculture and Rural Development of June 18 (2008), http://isap.sejm.gov.pl/isap.nsf/DocDetails.xsp? $\mathrm{id}=$ WDU20081190765, Accessed 27/03/2021

Regulation (EU) 2019/1009 of the European Parliament and of the Council of 5 June 2019 laying down rules on the making available on the market of EU fertilising products and amending Regulations (EC) No 1069/2009 and (EC) No 1107/2009 and repealing Regulation (EC) No 2003/2003, EUR-Lex 32019R1009 - EN - EUR-Lex (europa.eu), Accessed 27/03/2021

Rettig S, Schulz K, Barjenbruch M, Al-Zrejquat I (2018) Comparative indicators of energy efficiency, City of Turku, ISBN: 978 952-5991-38-3 (PDF)

Robescu LD, Presură E (2017) reducing carbon footprint of a wastewater treatment plant using advanced treatment and renewable energy source. Environ Eng Manag J 16(5):1055-1062

Rybicki S (2019) New technologies of water and wastewater treatment in relation to the idea of Smart Cities [in Polish] Wodociagi Polskie 1/53, https://www.igwp.org.pl/index.php/infor macje/technika/1155-nowe-technologie-oczyszczania-wody-isciekow-wobec-idei-smart-cities\#.site

Sarpong G, Gude VG (2020) Near future energy self-sufcient wastewater treatment schemes. Int J Environ Res. https://doi.org/10. 1007/s41742-020-00262-5

Sfez S, De Meester S, Vlaeminck SE, Dewulf J (2019) Improving the resource footprint evaluation of products recovered from wastewater: A discussion on appropriate allocation in the context of circular economy. Resour Conserv Recycl 148:132-144

Smol M, Adam C, Preisner M (2020) Circular economy model framework in the European water and wastewater sector. J 
Mater Cycles Waste Manage 22:682-697. https://doi.org/10. 1007/s10163-019-00960-Z

Song Y, Li H, Han Y, Lu C, Hou Y, Zhang Y, Guo J (2020) Landfill leachate as an additional substance in the Johannesburg-Sulfur autotrophic denitrification system in the treatment of municipal wastewater with low strength and low $\mathrm{COD} / \mathrm{TN}$ ratio. Bioresource Technology 295: 122287

Statista $2021 \mathrm{https}: / / \mathrm{www}$.statista.com/statistics/863335/sewagesludge-gas-energy-production-in-the-european-union-eu/. Accessed 21/03/2021

Strategy for dealing with municipal sewage sludge for 2019-2022 [in Polish]. Ministry of Environment, Poland, (2018), https:// www.gov.pl/attachment/2846e2b3-68c7-46eb-b36e-7643e81efd 9a. Accessed 29/03/2021

Tobin T, Gustafson R, Bura R et al (2020) Integration of wastewater treatment into process design of lignocellulosic biorefineries for improved economic viability. Biotechnol Biofuels 13:24. https:// doi.org/10.1186/s13068-020-1657-7

Trimmer JT, Cusick RD, Guest JS (2017). Amplifying Progress toward Multiple Development Goals through Resource Recovery from Sanitation. Environmental Science \& Technology, acs. est.7b02147-. doi:https://doi.org/10.1021/acs.est.7b02147

van Dijk KC, Lesschen JP, Oenema O (2015). Phosphorus flows and balances of the European Union Member States. Science of The Total Environment, 542B, 1078-1093, S0048969715305519-. doi:https://doi.org/10.1016/j.scitotenv.2015.08.048

Urban Waste Water Directive Overview. Available online: http://ec. europa.eu/environment/water/waterurbanwaste /index_en.html. Accessed18/06/2020

You X, Valderrama C, Cortina JL (2019) Nutrients recovery from treated secondary mainstream in an urban wastewater treatment plant: A financial assessment case study. Sci Total Environ 656:902-909

Vij S, Moors E, Kujawa-Roeleveld K, Lindeboom REF, Singh T, de Kreuk MK (2021) From pea soup to water factories: wastewater paradigms in India and the Netherlands. Environ Sci Policy 115:16-25

Wallis-Lage CL, Scanlan P, de Barbadillo C, Barnard J, Shaw A, Tarallo S (2015) The Paradigm Shift: Wastewater Plants to Resource Plants , https://www.researchgate.net/publication/272208871

Villarín MC, Merel S (2020) Paradigm shifts and current challenges in wastewater management, Journal of Hazardous Materials, 390. ISSN 122139:0304-3894. https://doi.org/10.1016/j.jhazmat.2020. 122139

Wróblewski J, Heidrich Z (2017) Energy consumption of municipal sewage treatment plants [in Polish] Gaz, Woda i Technika Sanitarna 8: 325-329, http://yadda.icm.edu.pl/yadda/element/bwmet a1.element.baztech-1f307659-1012-491e-beaa-4b5afdf45960

Wyrwik S (2020) Wastewater Recycling: Need or Obligation? Wodociagi i Kanalizacja 06.2020 https://yadda.icm.edu.pl/baztech/ element/bwmeta1.element.baztech-59050c0b-45a4-4052-99a5$291656 \mathrm{fa} 413 \mathrm{~b}$

Zarei M (2020) Wastewater resources management for energy recovery from circular economy perspective. Water-Energy Nexus 3:170-185

Publisher's Note Springer Nature remains neutral with regard to jurisdictional claims in published maps and institutional affiliations. 